\title{
Influence of dietary live yeast on European sea bass (Dicentrarchus labrax) larval development
}

\author{
D. Tovar-Ramírez ${ }^{a, b^{*}}$, J. Zambonino Infante ${ }^{b}$, C. Cahu ${ }^{b}$, F. J. Gatesoupe ${ }^{\text {b }}$ \\ and R. Vázquez-Juárez ${ }^{\mathrm{a}}$
}

\author{
${ }^{a}$ Centro de Investigaciones Biológicas del Noroeste (CIBNOR), Patologia Marina, POB 128, La Paz, BCS CP \\ 23000, Mexico \\ bUnité Mixte INRA-IFREMER de Nutrition des Poissons, BP 70, 29280, Plouzané, France \\ *: Corresponding author : Centro de Investigaciones Biológicas del Noroeste (CIBNOR), Patologia Marina, POB \\ 128, La Paz, BCS CP 23000, Mexico. Tel.: +52-612-1238518; fax: +52-612-1253625. dtovar04@cibnor.mx
}

\begin{abstract}
Recent results have demonstrated that live yeast in diets improved gut maturation in sea bass larvae. In this study, we tested the absence and two levels of live yeast in sea bass larvae diets. Specimens were fed from time of mouth opening to 37 days after hatching a diet of $0 \%, 1.1 \%$, or $5.7 \%$ wet weight of live yeast (Debaryomyces hansenii CBS 8339). Yeast incorporation improved survival $10 \%$, and reduced malformed larvae. In groups fed $1.1 \%$ yeast, only $1 \%$ of larvae were malformed, compared to $14 \%$ in the control group. Final mean weight in groups fed $1.1 \%$ yeast was twice that of other groups. Activities and concentrations of mRNA trypsin and lipase were higher in the two groups fed yeast than in the control group, whereas activity and concentration of mRNA amylase were lower. This suggests that the pancreas matured faster in the two groups fed yeast. Activities of intestinal enzymes alkaline phosphatase, aminopeptidase $\mathrm{N}$, and maltase in the group fed $1.1 \%$ yeast were higher than those in the two other groups, revealing earlier development of intestinal digestion. The best results were obtained with the diet containing $1.1 \%$ yeast cell biomass, corresponding approximately to $106 \mathrm{CFU}$ g-1 in the diet and $1.1 \times 104$ CFU per larva 30 days after hatching. The dose-dependent effect of yeast on rearing performance could be attributed to the amount of polyamines secreted by live yeast in the gut lumen of larvae.
\end{abstract}

Keywords: Author Keywords: Fish larvae; Gut maturation; Enzymes; Amylase, trypsin, lipase; Polyamines 


\section{Introduction}

As commercial aquaculture expands, juvenile marine fish production still depends on the supply of live food organisms. Compound diets are considered an alternative to live prey in rearing marine fish larvae (Cahu and Zambonino-Infante, 2001). Probiotics are microbial cells that are administered to enter and stay alive in the gastrointestinal tract with the aim of improving health, and might enhance the quality of farmed fish (Gatesoupe, 1999). Yeasts are promising candidates as probiotics, because of their abilities to produce polyamines and to adhere and grow in the intestinal mucus of fish (Buts et al., 1994; Vázquez-Juárez et al., 1997; Andlid et al., 1998; Tovar et al., 2002). Polyamines are ubiquitous molecules that participate in numerous biological processes (Tabor and Tabor, 1984), including cell replication and differentiation, and biosynthesis of nucleic acids and proteins (Bardócz et al., 1993). The role of dietary polyamines in mammals has been studied extensively, but literature concerning their effects on fish is scarce. Péres et al. (1997) observed a dosedependent effect of purified spermine on gut maturation in sea bass larvae weaned onto dry food. Recently, Tovar et al. (2002) incorporated live yeast by spraying different strains on pellets fed to sea bass larvae, from mouth opening onwards. These authors showed that Debaryomyces hansenii enhanced maturation of the digestive tract in marine fish larvae. It was suggested that the beneficial effect on the digestive tract was due to high secretion of spermine and spermidine by the yeast. Nevertheless, larval growth did not increase with the introduction of spermine or yeast in these preliminary experiments. The aims of the present study were to optimize the incorporation method and amount of live yeast in a compound diet.

\section{Materials and methods}

\subsection{Microorganisms}

The yeast, Debaryomyces hansenii (CBS 8339) was isolated from the gut of rainbow trout (Andlid et al., 1995). It was cultured in yeast extract peptone dextrose broth (YPD) (Sherman, 1991) until the early stationary phase. The cell suspension was then concentrated by centrifugation at $3000 \mathrm{xg}$, and rinsed with sterile water for $5 \mathrm{~min}$ at $4^{\circ} \mathrm{C}$. Five sea bass larvae were sampled at $30 \mathrm{dph}$ from each of the four replicates for microbiological counts, according to the method of Gatesoupe (1995). The yeast was counted on YPD agar supplemented with antibiotics (chloramphenicol, $1 \mathrm{mg} \mathrm{l}^{-1}$; polimyxin B sulfate, $1.6 \mathrm{mg} \mathrm{l}^{-1}$; Amoxicillin, $2.5 \mathrm{mg} \mathrm{l}^{-1}$ ).

\subsection{Animals and diets}

European sea bass larvae (Dicentrarchus labrax) were provided by the marine farm Aquanord (Gravelines, France) and reared at IFREMER, Centre de Brest until 37 days post hatching (dph). Larvae were distributed into 12 conical fiberglass tanks (35-1) at $2 \mathrm{dph}$, with initial stocking density of 60 larvae $1^{-1}$. They were supplied with running seawater which had been filtered through a sand filter, then passed successively through a tungsten heater and degassing column packed with plastic rings. Temperature range was $18-19^{\circ} \mathrm{C}$, salinity $34.5 \mathrm{ppt}$. Oxygen level was maintained above $6 \mathrm{ppm}$ by setting the water exchange up to 
$30 \%$ per h (flow rate: 0.181 per min). Light intensity was $9 \mathrm{Wm}^{-2}$ maximum at the surface. From 6 days post-hatching (dph) onwards, larvae were fed one of three compound diets, 4 tanks each, containing $1.1 \%$ yeast, $5.7 \%$ yeast, or no yeast (control). The $1.1 \%$ and $5.7 \%$ diets contained approximately $10^{6}$ and $6 \times 10^{6}$ colony-forming units (CFU) $\mathrm{g}^{-1}$, respectively. The basal diet (patent WO 0064273 ) contained $58.4 \%$ protein, $21.3 \%$ lipid (7.8\% neutral lipid and $11.6 \%$ phospholipid), $12.2 \%$ ash related to dry matter, and $9.8 \%$ moisture. The dietary ingredients, including yeast, were mixed with water, pelletized, and dried at $45^{\circ} \mathrm{C}$ for $20 \mathrm{~min}$. The pellets were sieved to obtain particles of two size ranges: 120-200 $\mu \mathrm{m}$, and 200-400 $\mu \mathrm{m}$. The larvae were fed in excess with belt feeders $18 \mathrm{~h}$ per day, with 120-200 $\mu \mathrm{m}$ particles from 6 to $20 \mathrm{dph}$, and with 200-400 $\mu \mathrm{m}$ particles thereafter.

\subsection{Sampling and dissection}

Larval growth for each dietary group was determined every week on the morning before feeding at 13,20,27,34, and $37 \mathrm{dph}$ by sampling 10 larvae tank ${ }^{-1}$ (4 tanks per dietary group). These sampling days correspond to critical developmental phases of digestive functions of sea bass larvae (Cahu and Zambonino Infante, 1994). For enzymatic analysis, 50 larvae were collected from each tank on day 26 and 36. Another 60 larvae were collected for mRNA studies from only 3 tanks the same sampling days, following the method of Cahu and Zambonino Infante (1994). Dissection produced a crude mixture of organs of each segment. The pancreatic segment contained pancreas, liver, heart, muscle, spine and a very short portion of intestine. The intestinal segment contained intestine, muscle, and spine. Nevertheless, the assays revealed actual gut digestive activity, since the enzymes assayed were located mainly in digestive organs (Zambonino et al., 1997). Larvae for enzymatic assays were frozen and stored at $-80^{\circ} \mathrm{C}$ until determination, and those for RNA extraction were processed immediately. At the end of the experiment, survival was determined by counting the individuals in each tank, and spinal malformation by examining 50 larvae per tank with a binocular microscope.

\subsection{Enzymatic measurements}

Pancreatic segments were homogenized in 5 volumes $(\mathrm{v} / \mathrm{w})$ of cold distilled water $\left(4^{\circ} \mathrm{C}\right)$ : final volumes were between 3 and $5 \mathrm{ml}$. The three pancreatic enzymes were assayed in duplicates using $50 \mu \mathrm{l}$ homogenate each. Trypsin activity was assayed according to Holm et al. (1988) using Na-benzoyl-DL arginine-p-nitroanilide (BAPNA, Sigma) as substrate. Amylase activity was assayed according to Métais and Bieth (1968), using iodine solution to reveal non-hydrolyzed starch. Lipase was assayed according to Iijima et al. (1998) using p-nitrophenyl myristate (Sigma) as substrate. Brush border membranes (BBM) from the intestinal segment were purified according to a method developed for intestinal scraping (Crane et al., 1979). BBM enzymes, aminopeptidase $\mathrm{N}$ (AN), maltase, and alkaline phosphatase (AP) were assayed according to Maroux et al. (1973), Dahlqvist (1970), and Bessey et al. (1946), respectively, expressed as IU/mg protein. Protein was determined according to Bradford (1976). 


\section{5. mRNA quantification}

TRIzol $^{\circledR}$ reagent (Gibco BRL) was used for total RNA extraction. Then, $5 \mu \mathrm{g}$ total RNA was reverse-transcribed to cDNA with the Ready To Go T-Primed First-Strand kit (Pharmacia Biotech). Primers and annealing temperatures are given in Table 1. Next, $50 \mu 1$ reaction mixture containing $1 \mu \mathrm{l}$ cDNA, $2.5 \mathrm{U}$ of Taq polymerase (Qbiogene), $40 \mathrm{nM}$ dNTPs (Eurogenetec), 50 pmol of each primer, 1X buffer solution (Qbiogene), and water sufficient to make $50 \mu \mathrm{l}$ solution were amplified in a thermocycler (Robocycler ${ }^{\circledR}$ gradient 96, Stratagene). PCR conditions were as follows: initial denaturation at $94^{\circ} \mathrm{C}$ for $30 \mathrm{sec}$, followed by 30 cycles including denaturation at $94^{\circ} \mathrm{C}$ for $1 \mathrm{~min}$, annealing at specific enzyme temperatures for $1.5 \mathrm{~min}$, and $2 \mathrm{~min}$ elongation at $72^{\circ} \mathrm{C}$. A final extension cycle was performed at $72^{\circ} \mathrm{C}$ for $7 \mathrm{~min}$. Quantification of RT-PCR products coding for each enzyme was performed by applying 2-10 $\mu \mathrm{l}$ of each product to a $3 \%$ agarose $-1 \mu \mathrm{g} / \mathrm{ml}$ ethidium bromide gel ( $2 \%$ agarose plus $1 \%$ low melting temperature agarose). The cDNA spots were captured in a multi-imager (Fluor S-Multimager System, Bio-Rad) and measured by software (Scion Image, available at http://www.scioncorp.com/). The quantification of mRNA coding for each enzyme was normalized relative to the mRNA-specific housekeeping gene glyceraldehyde-3-phosphate dehydrogenase (GAPDH). Values obtained for amylase, lipase, and trypsin were normalized to GAPDH by calculation of the mRNA of each enzyme/GAPDH mRNA.

Table 1. Primer sequences and annealing temperatures.

\begin{tabular}{llll}
\hline Primer & $5^{\prime}$ primer & 3' primer & $\begin{array}{l}\text { Annealing } \\
\text { temperature }\end{array}$ \\
\hline Trypsin $^{1}$ & CAggTgTCTCTgAAC & CCCA(Ag)gACACAACACCCT & $60^{\circ} \mathrm{C}$ \\
Amylase & TT(CT)gAgTggCgCTgg & (Ag)ggCCACATgTgCTT & $52^{\circ} \mathrm{C}$ \\
Lipase $^{2}$ & TGTggCTTCAACAgC & CgC TCCAAg(Ag)CT GTA & $50^{\circ} \mathrm{C}$ \\
GAPDH $^{1}$ & gCCATCAATgACCCCTT & ggTgCAggATgCATTgC & $50^{\circ} \mathrm{C}$ \\
$\begin{array}{l}{ }^{1} \text { Péres et al. (1998) } \\
{ }^{2} \text { This work }\end{array}$ & &
\end{tabular}

\subsection{Acquisition of cDNA probe coding for lipase}

cDNA was obtained as described above and primers specific for lipase (Table 1) were obtained by alignment of most conserved regions from those sequences that coded for triglyceride lipase of zebrafish (EMBL AW018709) and mice (EMBL X58426). Purified lipase fragment $(288 \mathrm{bp}$ ) was obtained according to the protocol of Geneclean Spin kit (BIO 101 Inc., USA) and cloned according the protocol of Topo Ta Cloning (Invitrogene, The Netherlands) into TOP $10 F^{\prime}$ competent cells, using the $\mathrm{pCR}^{\circledR} 2.1-\mathrm{TOPO}^{\circledR}$ as a vector. Plasmids were obtained by mini-prep according to RPM kit (BIO 101 Inc., USA) and sequenced. The resulting sequence was deposited at the European Bioinformatics Institute (EMBL) under access number AJ275976. 


\subsection{Statistical analysis}

The samples from each treatment ( 4 tanks; 3 tanks for mRNA studies) were maintained as separate entities and the results are given as mean \pm S.D ( $n=4 ; n=3$ for mRNA studies). Data on survival, and trypsin, amylase, and lipase secretion levels were arcsine transformed $\left(\arcsin x^{1 / 2}\right)$. The variance homogeneity of the data was checked, using Bartlett's test (Dagnelie, 1975). Data were compared by one-way ANOVA followed by Neuman Keul's multiple-range test when significant differences were found $(P<0.05)$.

\section{Results}

At $30 \mathrm{dph}$, yeast was recovered from the gut of sea bass larvae at the rate of $(1.1 \pm 0.2) \mathrm{x}$ $10^{4}$ and $(6.9 \pm 0.3) \times 10^{4} \mathrm{CFU}$ per larva fed $1.1 \%$ and $5.7 \%$ live yeast, respectively. The yeast was not detected in the control group.

The growth of larvae fed $1.1 \%$ live yeast was twice that of either of the two other dietary groups at 36 dph (Fig. 1). Also, survival of larvae fed either concentration of yeast was significantly higher than the control group (Table 2 ). The $1.1 \%$ yeast diet produced a larvae malformation rate $(1.1 \pm 1.63 \%)$ lower than either $5.7 \%$ yeast or the control $(6.5 \pm 2.81 \%$ and $13.6 \pm 5.53 \%$, respectively).

At $26 \mathrm{dph}$, trypsin-specific activity was higher in larvae fed either concentration of yeast than in control diet larvae (Fig. 2A). However, mRNA coding for trypsin on the same date was the same for all experimental groups (Fig. 2B). At $36 \mathrm{dph}$, the highest trypsin specific activity and mRNA concentrations were observed in the group fed $1.1 \%$ yeast. This trypsin activity should be considered as a trypsin-like activity since pancreatic segment contains a little portion of intestine. In contrast to trypsin, amylase specific activity at 26 and $36 \mathrm{dph}$ was higher in the control group than those fed yeast (Fig. 3A). The mRNA ratios also were highest for the control group at $36 \mathrm{dph}$ (Fig. 3B). Amylase mRNA levels were the same for all groups at $26 \mathrm{dph}$.

At 26 and 36 dph, specific lipase activity was higher in larvae fed yeast (Fig. 4A). However, at 26 and $36 \mathrm{dph}$, mRNA concentration for this enzyme was not significantly different in any group (Fig. 4B).

At 26 dph, higher specific activities for brush border membrane enzymes AP, maltase, and AN were observed in larvae fed $1.1 \%$ yeast (Fig. 5). At $36 \mathrm{dph}$, all groups presented the same enzymatic activity. 
Table 2. Percent survival and spinal deformity of sea bass larvae fed with or without (control) diets supplemented with yeast. Results relating to survival are presented as means \pm SD of quadruplicate observations. Total number of larvae employed per tank at trial start was $2100(n=8400$ per treatment). Observations relating to spinal deformity were made for 50 animals $\operatorname{tank}^{-1}(n=200$ treatment $^{-1}$ ).

\begin{tabular}{lll}
\hline Group & Survival (\%) & Larvae with spinal malformation (\%) \\
\hline Control & $42.4 \pm 0.79^{\mathrm{b}}$ & $13.6 \pm 5.53^{\mathrm{a}}$ \\
$1.1 \%$ CBS 8339 & $46.3 \pm 0.82^{\mathrm{a}}$ & $1.1 \pm 1.63^{\mathrm{b}}$ \\
$5.7 \%$ CBS 8339 & $45.8 \pm 0.30^{\mathrm{a}}$ & $6.5 \pm 2.81^{\mathrm{a}}$ \\
\hline
\end{tabular}

Figure 1. Growth of $D$. labrax larvae fed a control diet and two diets containing different percentages of yeast. Each data point represents observations for 40 randomly taken larvae treatment ${ }^{-1}$. Means \pm SD with different superscripts for the $37 \mathrm{dph}$ are significantly different $(P<0.05)$.

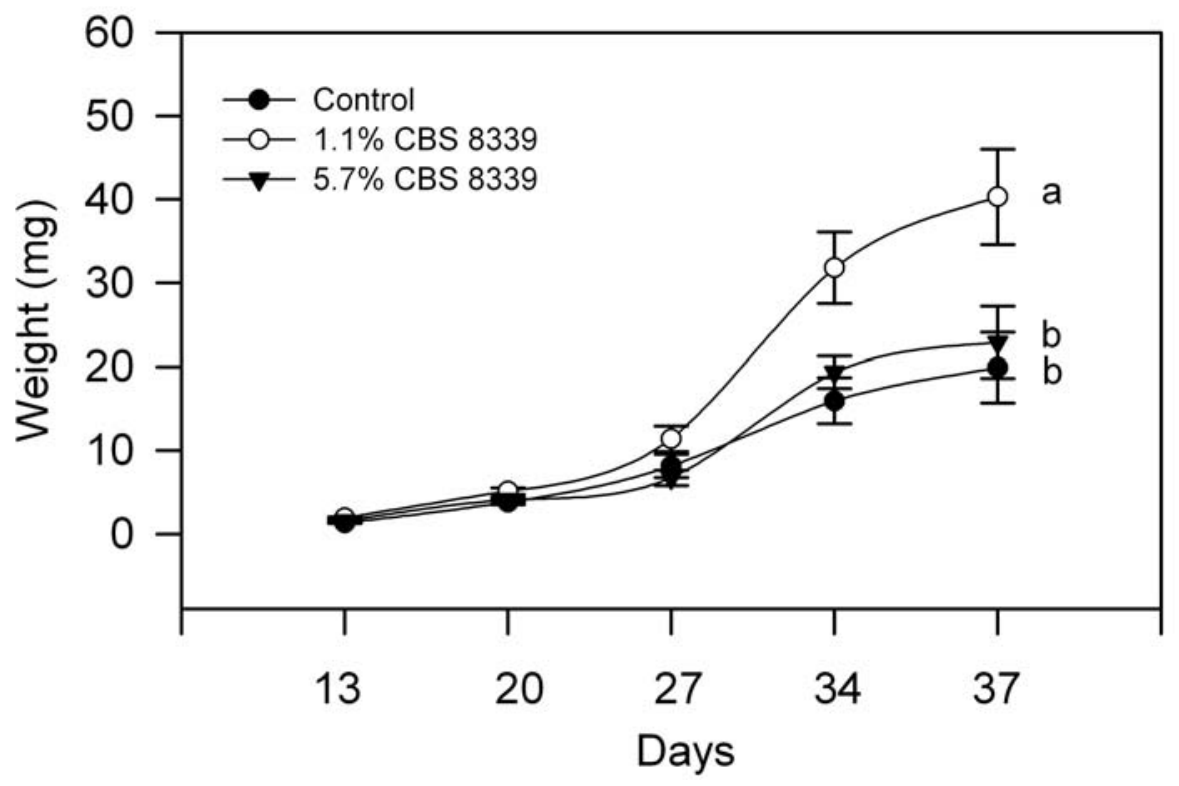


Figure 2. Trypsin-like activity (A) and ratio of mRNA trypsin to mRNA GAPDH concentrations (B) in pancreatic segments of $D$. labrax larvae fed a control diet and two diets containing yeast, at 26 and 36 dph. Means \pm SD ( $n=4$ for enzymes activities; $n=3$ for RNA ratios) for the same day with different superscripts are significantly different $(P<0.05)$.
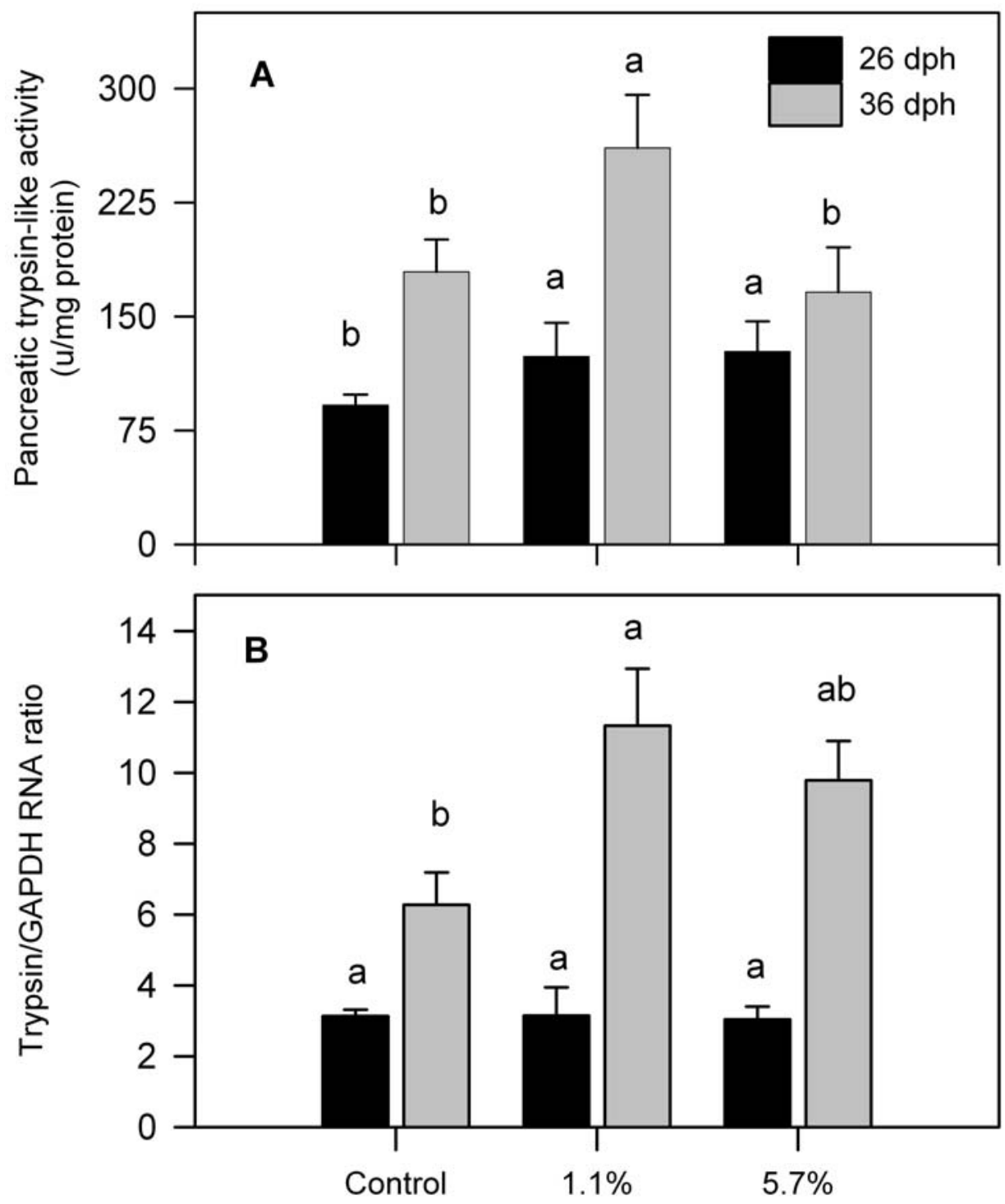
Figure 3. Amylase activity (A) and ratio of mRNA amylase to mRNA GAPDH concentrations (B) in pancreatic segments of $D$. labrax larvae fed a control diet and two diets containing yeast, at 26 and 36 dph. Means \pm SD ( $n=4$ for enzymes activities; $n=3$ for RNA ratios) for the same day with different superscripts are significantly different $(P<0.05)$.

Figure 4. Lipase activity (A) and ratio of mRNA lipase to mRNA GAPDH concentrations (B) in pancreatic segments of $D$. labrax larvae fed a control diet and two diets containing yeast, at 26 and 36 dph. Means \pm SD ( $n=4$ for enzymes activities; $n=3$ for RNA ratios) for the same day with different superscripts are significantly different $(P<0.05)$.

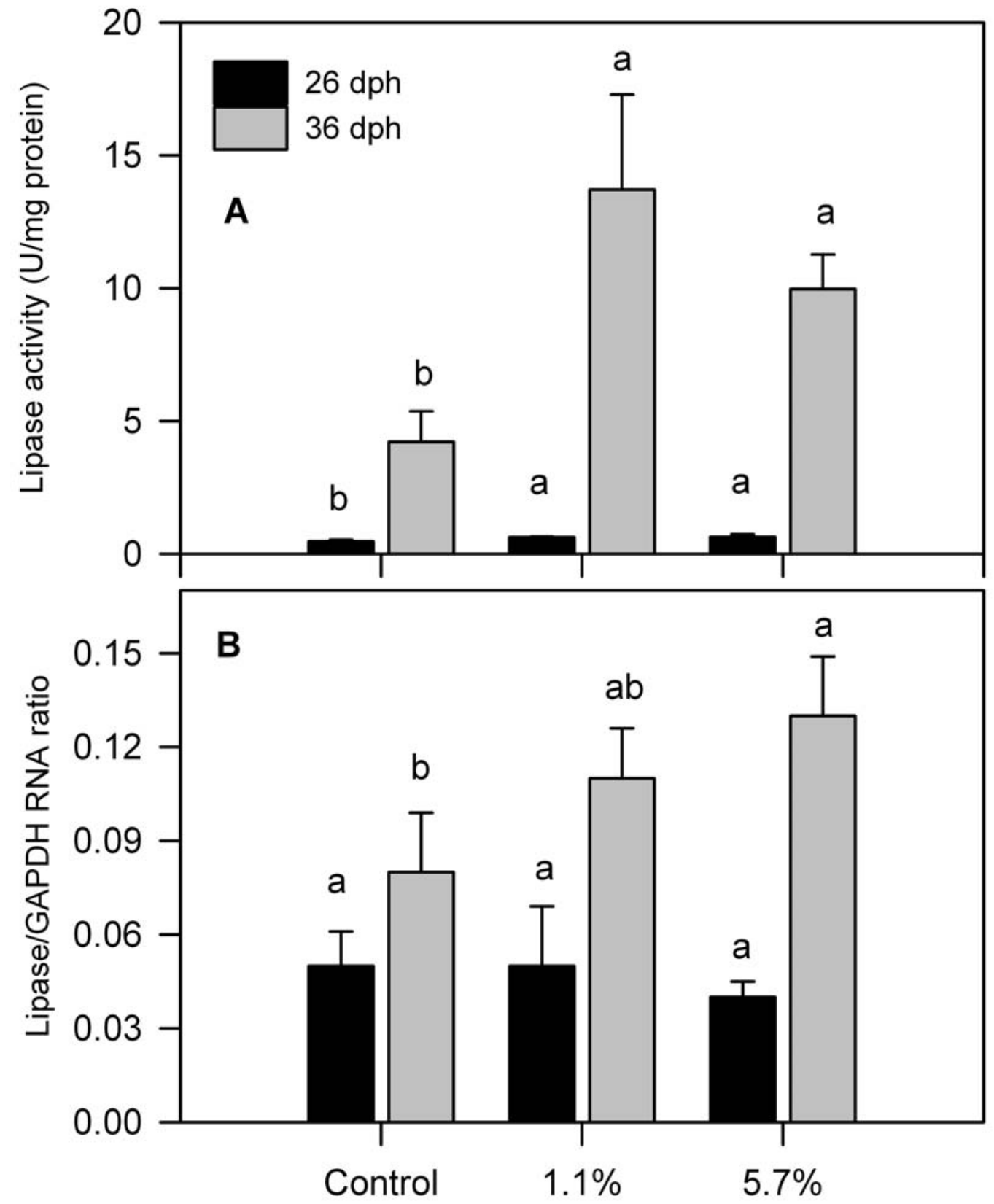


Figure 5. Specific activity of alkaline phosphatase (AP), maltase and aminopeptidase $N$ (AN) from brush border membrane of $D$. labrax larvae fed diet and diets containing two levels of yeast at 26 and $36 \mathrm{dph}$. Means \pm SD $(n=4)$ with different superscripts for the same day are significantly different $(P<$ 0.05).
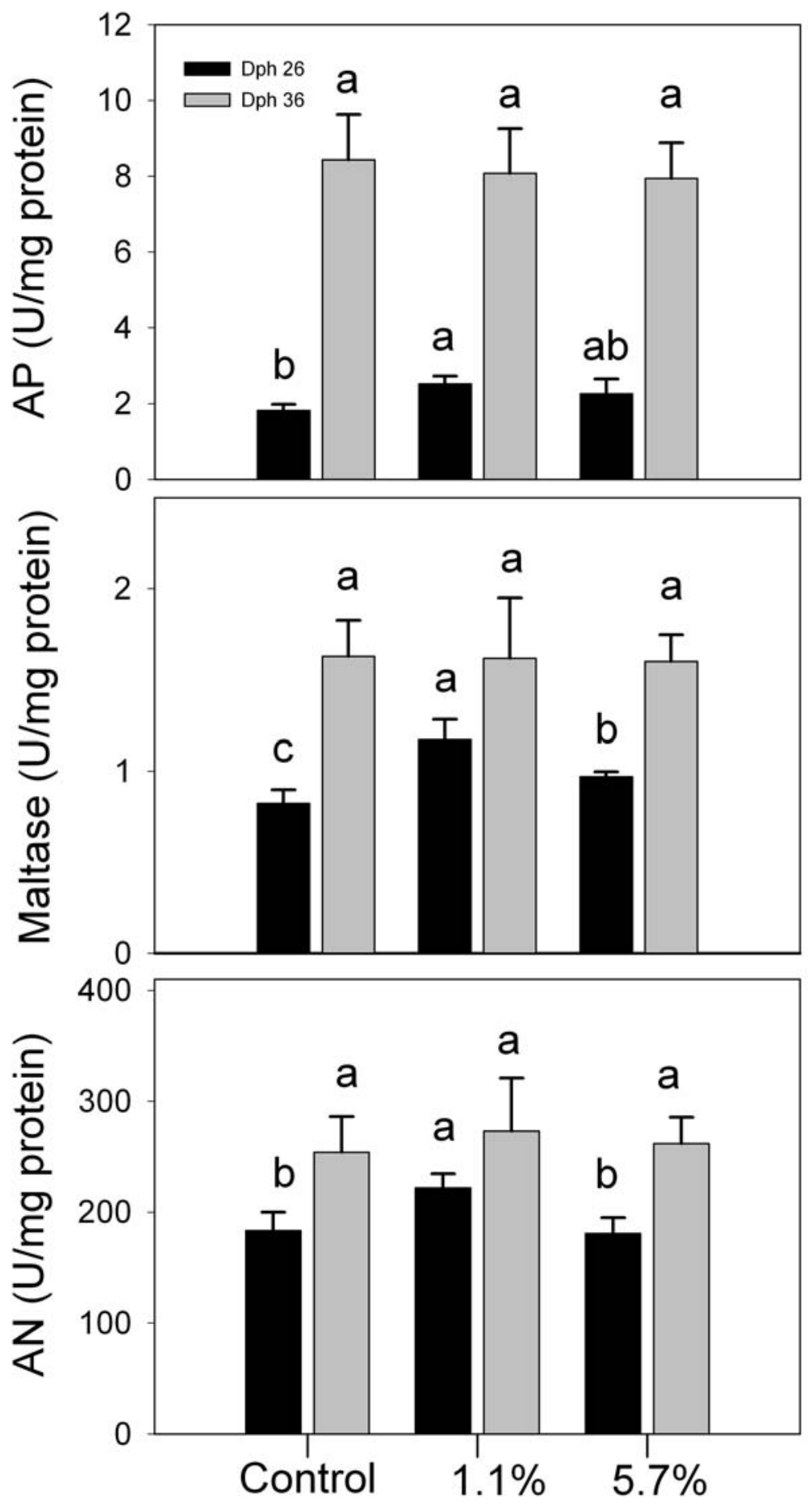


\section{Discussion}

Larvae survival and skeletal development were better in the two groups fed diets containing yeast than in the control group. Moreover, a marked effect on growth of fish larvae was noted for the first time. Growth improvement by live yeast incorporation in diet has been previously described in juvenile and adult fish. Noh et al. (1994) showed that dietary incorporation of live yeast (Saccharomyces cerevisiae) led to 10\% increase in weight gain in $4 \mathrm{~kg}$ carp. These effects have been demonstrated also in developing mammals, particularly in pigs (Bertin et al., 1997).

The beneficial effects of dietary live yeast seem particularly determinate in developing animals, since it affects survival, growth, and conformation. Interestingly, the effect on growth in our experiment was observed in the group fed $1.1 \%$ yeast but not in the group with $5.7 \%$ yeast. The amount of yeast retrieved from larvae was almost proportional to the dietary level, suggesting that yeast cells were kept alive in the gut, and that the yeast did not act through a direct nutritional effect. The incorporation of large proportions of inactive yeast up to $50 \%$ of dietary ingredients in fish diet was tested as a protein source alternative to fish meal, but no significant improvement in growth was reported (Métailler and Huelvan, 1993; Oliva-Teles and Gonçalves, 2001). The positive effects of live yeast might be due to molecules such as growth factors released by the yeast, and acting at low concentration. The yeast used in this experiment, Debaryomyces hansenii, secretes several polyamines in higher quantities than other strains incorporated in test diets for humans and animals (Table 3). Putrescine, spermine, and spermidine are considered essential growth factors (Bardócz, 1993).

Péres et al. (1997) reported enhanced survival in sea bass larvae fed diets containing purified spermine. Tovar et al. (2002) also observed a beneficial effect on sea bass survival by spraying live yeast on micropellets, but this incorporation method changed some physical properties of the microparticles, leading to a decrease in feed ingestion that adversely affected larva growth. Mixing yeast with raw material preserved the physical properties of micropellets. This new process, combined with a lower drying temperature $\left(45^{\circ} \mathrm{C}\right)$, improved yeast survival in fish larvae. This improvement was illustrated by the fact that $1.1 \times 10^{4} \mathrm{CFU}$ yeast larva ${ }^{-1}$ were recovered from larvae fed the diet containing $10^{6}$ CFU g ${ }^{-1}(1.1 \%)$, whereas $2.5 \times 10^{2} \mathrm{CFU} \mathrm{larva}^{-1}$ were retrieved in the previous experiment with the diet containing a similar dose of the same strain (ca. $7.5 \times 10^{5} \mathrm{CFU} \mathrm{g}^{-1}$, Tovar et al., 2002).

Table 3. Concentration of polyamines $(\mu \mathrm{mol} / \mathrm{g})$ measured in different yeast species.

\begin{tabular}{lccc}
\hline Yeast & Putrescine & Spermidine & Spermine \\
\hline S. boulardii $^{1}$ & 0.095 & 3.76 & 2.93 \\
${\text { S. } \text { cerevisiae }^{2}}^{\text {D. }{\text { hansenii, CBS } 8339^{3}}^{3}}$ & 0.45 & 2.00 & 0.30 \\
\hline
\end{tabular}

\footnotetext{
${ }^{1}$ Buts et al. (1994)

${ }^{2}$ Tabor and Tabor (1985)

${ }^{3}$ Tovar et al. (2002)
} 
A different mode of yeast action can be considered to explain the better performance of larvae fed live yeast. We hypothesized that live yeast induced better performance than inactive yeast or purified polyamines, because live yeast provided polyamines in situ in the intestine. Nevertheless, 5.7\% yeast and consequent high release of polyamines in the intestinal lumen did not lead to faster larval growth. The diet of these larvae contained $6.9 \times 10^{4} \mathrm{CFU}$ per individual, but their growth was close to that of the control in which Debaryomyces hansenii was not detected. It remains possible that increased levels of dietary yeast led to growth depression due to elevated levels of putrescine, as has been previously observed in chicks (Smith, 1990). Sousadias and Smith (1995) showed that spermine is more toxic than putrescine, and observed adverse effects on growth for dietary concentrations higher than $0.075 \%$.

The dietary incorporation of purified polyamines or live yeast that secrete polyamines influenced intestinal cell differentiation in developing and adult animals (Buts et al., 1994; Deloyer et al., 1996). In young animals, cell differentiation matures digestive functions of the intestine and pancreas in mammals (Peulen et al., 2000) and in fish (Péres et al., 1997). Maturation of the pancreas and intestine was characterized extensively for sea bass larvae fed live prey or compound diets (Cahu and Zambonino Infante, 1995). A recent review extended this description to larvae of other marine species (Zambonino Infante and Cahu, 2001). In our experiment, maturation of the exocrine pancreas of all dietary groups was observed between day 26 and day 36. This was a functional maturation, since pancreas organogenesis in sea bass is reached around 3 days post-hatching (Beccaria et al., 1991). After this time, a growth phase only has been reported for this organ. A decrease in amylase expression and an increase in trypsin and lipase expression during normal development were reported for sea bass larvae fed live prey (Cahu and Zambonino Infante, 1995; Zambonino Infante and Cahu, 1999). In our work, larvae fed yeast matured earlier than control after day 26, as revealed by lower amylase expression and higher lipase and trypsin expression.

Precocious maturation of intestinal cells was observed also in the larvae fed yeast. This was revealed at day 26 by higher activity of brush border membrane enzymes alkaline phosphatase, aminopeptidase $\mathrm{N}$, and maltase in these two groups than in control. Day 26 coincides with the beginning of the maturation process of enterocytes as described for larvae fed live prey (Cahu and Zambonino Infante, 1995). Cahu and Zambonino Infante (1995) reported that higher activities in brush border membranes of young larvae were correlated with higher survival. The three groups apparently matured at day 36 since their enzyme activities were the same at that time.

Polyamines seem to have a broad influence on digestive tract maturation. Particularly, the roles of dietary spermine and spermidine were described by Dufour et al. (1988). These molecules enter enterocytes, inducing a hormonal cascade that affects organs like the pancreas and liver (Peulen et al., 2000). In our experiment, it is likely that the polyamines secreted by yeast influenced pancreatic maturation by enhanced transcription of trypsin and lipase expression, and lowered amylase messenger transcription.

Assimilation of polyamines enhanced maturation and induced a pattern of adult enzyme expression in sea bass larvae, as observed by Péres et al. (1997), who used synthetic spermine. In this sense, D. hansenii strain CBS 8339 appears to be a good candidate for diet supplementation because it adheres to the gastric mucus (Vázquez-Juárez et al., 1997) and produces polyamines in situ. D. hansenii_produces significant amounts of putrescine. 
However, spermidine and spermine are considered the "right polyamines" because putrescine is converted mainly to non-polyamine metabolites (Bardócz et al., 1993).

The beneficial effects of live yeast on sea bass larvae development could be attributed to the role of polyamines in promoting intestinal maturation and increasing the ability of enterocytes to absorb nutrients. Bardócz et al. (1993) argued that polyamine requirements are higher in young animals during periods of intensive growth. However, the results of our experiment indicate that Debaryomyces hansenii yeast population should not exceed approximately $10^{4} \mathrm{CFU}$ larva $^{-1}$ for an optimum effect in sea bass development.

\section{Acknowledgements}

This study is a part of program PM98S03, supported by the French-Mexican Committee ECOS-Nord, and partially financed by the Consejo National de Ciencia y Tecnologia (CONACYT Project 25956B). The first author was supported also by CONACYT fellowship 84016 and by the French National Institute for Agronomic Research (INRA). CIBNOR editing staff suggested improvements to the text.

\section{References}

Andlid, T., Vázquez-Juárez, R., Gustafsson, L., 1995. Yeast colonizing the intestine of rainbow trout (Salmo gairdneri) and turbot (Scophthalmus maximus). Microb. Ecol. 30, 321-334.

Andlid, T., Vázquez-Juárez, R., Gustafsson, L., 1998. Yeasts isolated from the intestine of rainbow trout adhere to and grow in intestinal mucus. Mol. Mar. Biol. Biotechnol. 7, $115-126$.

Bardócz, S., 1993. The role of dietary polyamines. Eur. J. Clin. Nutr. 47, 683-690.

Bardócz, S., Grant, G., Brown, D.S., Ralph, A., Pusztai, A., 1993 Polyamines in foodimplications for growth and health. J. Nutr. Biochem. 4, 66-71.

Beccaria, C., Diaz, J.P., Connes, R., Chatain, B., 1991. Organogenesis of the exocrine pancreas in the sea bass, Dicentrarchus labrax, reared extensively and intensively. Aquaculture 99, 339-354.

Bertin, G., Brault, M., Baud, M., Mercier, M., Tournut, J., 1997. Saccharomyces cerevisiae I-1079, microbial feed additive: zootechnical effects on piglets. Annual meeting of the European Association for Animal Production, Vienna (Austria), August 25-28, Wageningen Press, Wageningen (NLD), 418 pp.

Bessey, O.A., Lowry, O.H., Brock, M.J., 1946. Rapid coloric method for determination of alkaline phosphatase in five cubic millimeters of serum. J. Biol. Chem. 164, 321-329.

Bradford, M.M., 1976. A rapid and sensitive method for the quantitation of microgram quantities of protein utilizing the principle of protein-dye binding. Anal. Biochem. 72, 248-254.

Buts, J.P., Keyser, N., Raedemaeker, L., 1994. Saccharomyces boulardii enhances rat intestinal enzyme expression by endoluminal release of polyamines. Pediatric Res. 36, 522-527.

Cahu, C.L., Zambonino-Infante, J.L., 1994. Early weaning of sea bass (Dicentrarchus labrax) larvae with a compound diet: effect on digestive enzymes. Comp Biochem Physiol 109, 213-222. 
Cahu, C.L., Zambonino-Infante, J.L., 1995. Maturation of the pancreatic and intestinal digestive functions in sea bass (Dicentrarchus labrax): effect of weaning with different protein sources. Fish Physiol. Biochem. 14, 431-437.

Cahu, C.L., Zambonino-Infante, J.L., 2001. Substitution of live food by formulated diets in marine fish larvae. Aquaculture 200, 161-180.

Crane, R.K., Boge, G., Rigal, A., 1979. Isolation of brush border membranes in vesicular form from the intestinal spiral valve of the small dogfish (Scyliorhinus canicula). Biochim. Biophys. Acta 554, 264-267.

Dagnelie, P., 1975. Les méthodes de l'inférence statistique. In: Ducolot, J. (Ed.), Théorie et Méthodes Statistiques, Vol 2. Gembloux, Belgium: Les Presses Agronomiques de Gembloux, pp. 1-463.

Dahlqvist, A., 1970. Assay of intestinal disaccharidase. Enzym. Biol. Clin. 1, 52-56.

Deloyer, P., Dandrifosse, G., Bartholomeus, C., Romain, N., Klimek, M., Salmon, J., Gérard, P., Goessens, G., 1996. Polyamine and intestinal properties in adult rats. Br. J. Nutr. 76, 627-637.

Dufour, C., Dandrifosse, G., Forget, P., Vermesse, F., Romain, N., Lepoint, P., 1988. Spermine and spermidine induce intestinal maturation in the rat. Gastroenterol. 95, 112-116.

Gatesoupe, F.J., 1995. A method for the early assessment of the quality of turbot larvae. Aquacult. Int. 3, 150-154.

Gatesoupe, F.J., 1999. The use of probiotics in aquaculture. Aquaculture 180, 147-165.

Holm, H., Hanssen, L.E., Krogdahl, A., Florholmen, J., 1988. High and low inhibitor soybean meals affect human duodenal proteinase activity differently: in vivo comparison with bovine serum albumin. J. Nutr. 118, 515-520.

Iijima, N., Tanaka, S., Ota, Y., 1998. Purification and characterization of bile salt-activated lipase from the hepatopancreas of red sea bream, Pagrus major. Fish Physiol. Biochem. 18, 59-69.

Maroux, S., Louvard, D., Baratti, J., 1973. The aminopeptidase from hog-intestinal brush border. Biochim Biophys. Acta . 321,282-295.

Métailler, R., Huelvan, C., 1993. Uitilisation des levures dans l'alimentation du juvénile de bar (Dicentrarchus labrax). In: Kaushik, S.J., Luquet, P. (Eds.) Fish Nutrition in Practice, Les Colloques, No. 61. Institut National de la Recherche Agronomique, Paris, pp. 945-948.

Métais, P., Bieth, J., 1968. Détermination de l' $\alpha$-amylase par une microtechnique. Ann. Biol. Clin. 26, 133-142.

Noh, S.H., Han, K., Won, T.H., Choi, Y.J., 1994. Effect of antibiotics, enzyme, yeast culture and probiotics on the growth performance of Israeli carp. Korean J. Anim. Sci. $36,480-486$.

Oliva-Teles, A., Gonçalves, P., 2001. Partial replacement of fishmeal by brewers yeast (Saccharomyces cerevisiae) in diets for sea bass (Dicentrarchus labrax) juveniles. Aquaculture 202, 269-278.

Peulen, O., Deloyer, P., Grandfils, C., Loret, S., Dandrifosse, G., 2000. Intestinal maturation induced by spermine in young animals. Livestock Prod. Sci. 66, 109-120.

Péres, A., Cahu, C.L., Zambonino-Infante, J.L., 1997. Dietary spermine supplementation induces intestinal maturation in sea bass (Dicentrarchus labrax) larvae. Fish. Physiol. Biochem. 16, 479-485. 
Péres, A., Zambonino-Infante, J.L., Cahu, C., 1998. Dietary regulation of activities and mRNA levels of trypsin and amylase in sea bass (Dicentrarchus labrax) larvae. Fish Physiol. Biochem. 19, 145-152.

Sherman, F., 1991. Getting started with yeast. In: Guthrie, C., Fink, G.R., (Eds.) Guide to Yeast Genetics and Molecular Biology, Methods in Enzymology 194. New York: Academic Press, pp. 3-21.

Smith, T.K., 1990. Effect of dietary putrescine on whole body growth and polyamine metabolism. Proc. Soc. Exp. Biol. Med. 194, 332-336.

Sousadias, M.G., Smith, T.K., 1995. Toxicity and growth-promoting potential of spermine when fed to chicks. J. Anim. Sci. 73, 2375-2381.

Tabor, C.W., Tabor, H., 1984. Polyamines. Ann. Rev. Biochem 53, 749-790.

Tabor, C.W., Tabor, H., 1985. Polyamines in microorganisms. Microbiol. Rev. 49, 81-99.

Tovar, D., Zambonino-Infante, J.L., Cahu, C., Gatesoupe, F.J., Vázquez-Juárez, R., Lésel, R., 2002. Effect of live yeast incorporation in compound diet on digestive enzyme activity in sea bass larvae. Aquaculture 204, 113-123.

Vázquez-Juárez, R., Andlid, T., Gustafsson, L., 1997. Adhesion of yeast isolated from fish gut to crude intestinal mucus of rainbow trout, Salmo gairdneri. Mol. Mar. Biol. Biotechnol. 6, 64-71.

Zambonino-Infante, J.L, Cahu, C.L., Péres, A. 1997. Partial substitution of di- and tripeptides for native proteins in sea bass diet improves Dicentrarchus labra larval development. J. Nutr. 127, 608-614.

Zambonino-Infante, J.L., Cahu, C.L., 1999. High dietary lipid levels enhance digestive tract maturation and improve Dicentrarchus labrax development. J. Nutr. 129, 1195-1200.

Zambonino-Infante, J.L., Cahu, C.L., 2001. Ontogeny of the gastrointestinal tract of marine fish larvae-Review. Comp. Biochem. Physiol. 130, 477-487. 